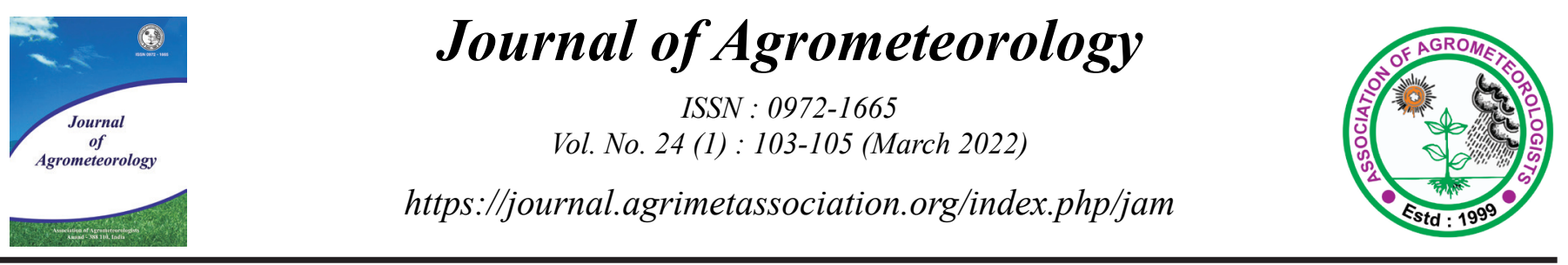

Short Communication

\title{
Mulching effect on soil temperature, weed management, growth and flower yield in rose (Rosa hybridaL.)
}

\section{R. SINGH and T. THAKUR*}

Department of Floriculture and Landscaping, Punjab Agricultural University, Ludhiana, India

Corresponding author email : tanyathakurflori@gmail.com

Crop yield and productivity can be increased by mulching as it improves soil temperature, soil moisture, weed control, reduction in leaching of fertilizers and increases the nutrient availability (Bohra et al., 2015). Polyethylene film mulch is preferred mulching material in horticultural crops owing to its greater permeability to long wave radiation which increases the soil temperature during night in winters. Application of mulching alters crop microclimate that might be useful for maximum fruit yield and lesser disease (Saha et al., 2010). Therefore, the aim of investigation was to evaluate different mulching materials on growth, flowering and weed suppression in rose. The present experiment was carried out at the Department of Floriculture and Landscaping, Punjab Agricultural University, Ludhiana to find out the effectiveness of different mulching material on growth, flowering and weed suppression in rose grown under open field conditions. Plants were planted in each plot at $60 \times 45 \mathrm{~cm}$ distance after spreading the mulching material on soil. The experiment was laid out in Randomized Block Design, comprising eight treatments replicated thrice. The treatments comprising of mulching material are Black Polyethylene Mulch (BPM)@ 50 micron $(\mu)$ thick, Black Polyethylene Mulch@100 $\mu$ thick, Black Polyethylene Mulch @ $200 \mu$ thick, White Polyethylene Mulch (WPM)@ @ $50 \mu$ thick, White Polyethylene Mulch@100 $\mu$ thick, White Polyethylene Mulch@200 $\mu$ thick, Paddy Straw Mulch (PSM)@6 tones/ha and weedy control (without mulch). The observations like plant height (cm), number of branches per plant, days taken to flowering, flower duration (days), flower diameter $(\mathrm{cm})$, number of flowers per plant, number of flowers per unit area, weed count, fresh and dry weight of weeds were recorded for two years and polled for statistical analysis through ANOVA test.

\section{Plant growth and flower quality}

The growth and flower quality parameters were significantly affected by different mulching material for pooled data of both the years as presented in Table 1. The plant height was recorded maximum in paddy straw mulch $(63.78 \mathrm{~cm})$ which was significantly different from all other treatments, except for white polythene mulch $50 \mu(61.64 \mathrm{~cm})$. The minimum plant height was observed under weedy control $(53.45 \mathrm{~cm})$ which was at par with black polythene mulch $50 \mu(55.86 \mathrm{~cm})$. The number of branches per plant was significantly better under paddy straw mulch (10.04) followed by white polythene mulch $50 \mu(9.03)$ and white polythene mulch $100 \mu$, which were at par. The minimum number of branches were recorded in black polythene mulch $200 \mu$ (6.88) followed by black polythene mulch $100 \mu$ (7.37) which were at par with each other.

It was observed that growth parameters were better in plants with mulching than non-mulched plants with maximum growth under paddy straw mulch as it has more capacity to regulate optimum soil temperature for plant growth and improving microclimate. These results are in conformity with findings of Hudu et al., (2002).

The earliest flowering was recorded in white polythene mulch $200 \mu$ (53.38 days) followed by paddy straw mulch (53.66 days), white polythene mulch $50 \mu$ (54.04 days), which were at par with each other. The maximum days to flowering was recorded in black polythene mulch $200 \mu$ (57.87 days) followed by black polythene mulch $100 \mu$ (57.50 days) and black polythene mulch $50 \mu$ (56.49 days) which were at par with each other. The longest duration of flowering was reported in black polythene mulch $200 \mu$ (101.36 days) followed by black polythene mulch 50 and $100 \mu(98.97$ days) and white polythene mulch $200 \mu$ (98.53 days) which were at par with each other. The shortest flower duration was observed in weedy control (88.11 days) which differs significantly from other

Article info - DOI: https://doi.org/10.54386/jam.v24i1.787

Received: 30 April 2021; Accepted: 29 December 2021; Published online: 11 February 2022

This work is licenced under a Creative Common Attribution 4.0 International licence@Author(s),Publishing right@ Association of Agrometeorologists 
Table 1: Effect of different mulching material on growth and flower quality of rose

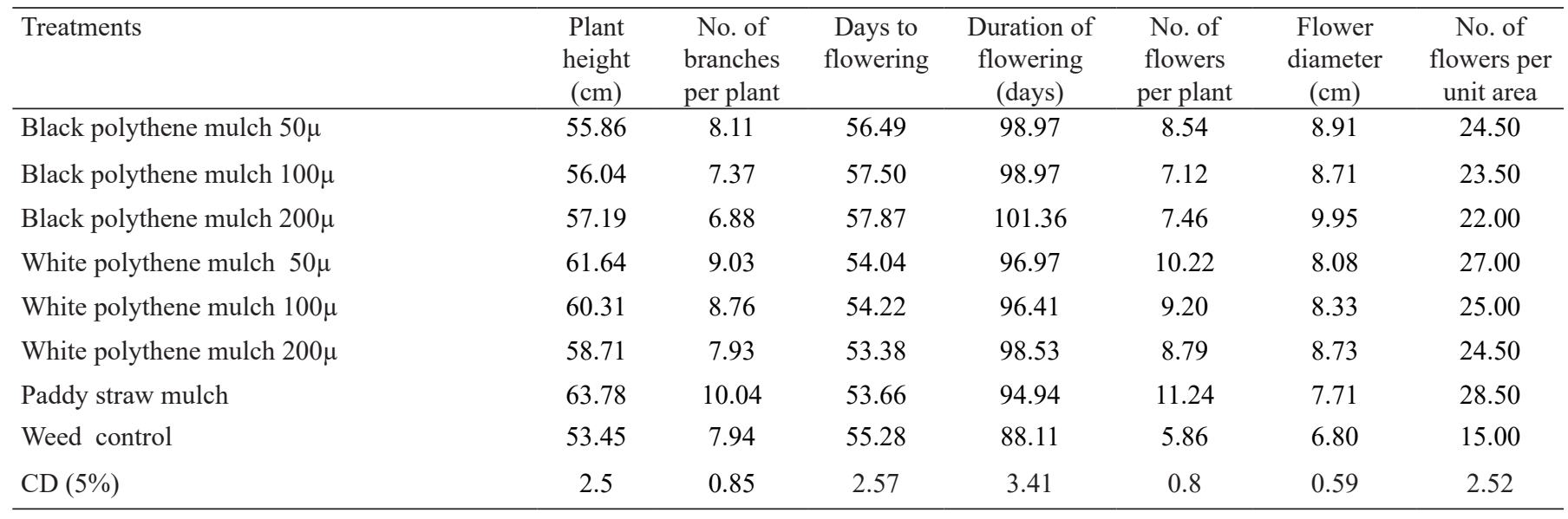

Table 2: Effect of different mulching material on weed parameters in rose

\begin{tabular}{|c|c|c|c|c|c|c|c|c|c|}
\hline \multirow[t]{2}{*}{ Treatments } & \multicolumn{3}{|c|}{ Weed count } & \multicolumn{3}{|c|}{ Weed fresh weight (g) } & \multicolumn{3}{|c|}{ Weed dry weight (g) } \\
\hline & 50 days & 75 days & 100 days & 50 days & 75 days & 100 days & 50 days & 75 days & 100 days \\
\hline Black polythene mulch $50 \mu$ & 0.00 & 0.50 & 0.50 & 0.0 & 0.00 & 0.00 & 0.00 & 0.00 & 0.00 \\
\hline Black polythene mulch $200 \mu$ & 0.00 & 0.00 & 0.00 & 0.00 & 0.00 & 0.00 & 0.00 & 0.00 & 0.00 \\
\hline White polythene mulch $50 \mu$ & 9.18 & 13.85 & 16.34 & 4.69 & 8.185 & 9.855 & 0.133 & 1.985 & 3.845 \\
\hline White polythene mulch $100 \mu$ & 6.53 & 8.66 & 8.94 & 2.97 & 5.965 & 6.28 & 0.2975 & 0.314 & 0.957 \\
\hline Paddy straw mulch & 5.84 & 27.00 & 41.75 & 3.24 & 17.36 & 55.27 & 1.003 & 2.0375 & 3.122 \\
\hline Weed control & 85.83 & 224.01 & 293.57 & 15.865 & 248.11 & 366.42 & 1.6565 & 3.849 & 6.544 \\
\hline $\mathrm{CD}(5 \%)$ & 1.54 & 2.51 & 3.05 & 0.57 & 1.47 & 6.11 & 0.12 & 0.89 & 0.18 \\
\hline
\end{tabular}

Table 3: Effect of different mulching treatments on soil temperature $\left({ }^{\circ} \mathrm{C}\right)$

\begin{tabular}{lccccc}
\hline Treatments & October & November & December & January & February \\
\hline Black polythene mulch $50 \mu$ & 15.3 & 12.7 & 10.8 & 13.4 & 15.9 \\
Black polythene mulch $100 \mu$ & 15.9 & 12.9 & 11.1 & 13.3 & 13.9 \\
Black polythene mulch $200 \mu$ & 16.4 & 13.3 & 13.8 & 13.3 & 13.7 \\
White polythene mulch $50 \mu$ & 15.8 & 13.1 & 10.9 & 13.4 & 13.6 \\
White polythene mulch $100 \mu$ & 15.6 & 12.6 & 10.6 & 13.6 & 13.4 \\
White polythene mulch $200 \mu$ & 15.9 & 12.6 & 10.6 & 13.5 & 15.2 \\
Paddy straw mulch & 16.2 & 13.1 & 10.9 & 12.9 & 13.6 \\
Weed control & 15.5 & 12.5 & 10.8 & 13.1 & 13.8 \\
\hline
\end{tabular}

treatments, followed by paddy straw mulch (94.94 days) and white polythene mulch $100 \mu$ (96.41 days) which were at par with each other. The delayed flowering under black polythene mulch may be due to increased soil temperature at the time of flower bud initiation $\left(16.4^{\circ} \mathrm{C}\right)$ which detained the process of flowering, whereas optimum temperature under white polythene mulch and paddy straw mulch facilitated the flowering process.

The maximum number of flowers per plant was recorded in paddy straw mulch (11.24) followed by white polythene mulch $50 \mu$ (10.22) and white polythene mulch $100 \mu$ (9.20) which differs significantly from each other. The minimum number of flowers per plant was observed in weedy control (5.86) followed by black polythene mulch $100 \mu$ (7.12) and black polythene mulch $200 \mu$ (7.46), which were at par with each other. The number of flowers per area was recorded highest in paddy straw mulch (28.50) which was at par with white polythene mulch $50 \mu$ (27.00) followed by white polythene mulch $100 \mu(25.00)$. The lowest number of flowers per area was observed in weedy control (15.00) which differs significantly from other treatments, followed by black polythene mulch $200 \mu$ (22.00). The flower diameter was largest in black polythene mulch $200 \mu(9.95 \mathrm{~cm})$ followed by black polythene mulch $50 \mu(8.91 \mathrm{~cm})$ and white polythene mulch $200 \mu(8.73 \mathrm{~cm})$ which was at par with each other. The minimum flower diameter was observed in weedy control $(6.80 \mathrm{~cm})$ which differs significantly 
from other treatments followed by paddy straw mulch $(7.71 \mathrm{~cm})$ and white polythene mulch $50 \mu(8.08 \mathrm{~cm})$, at par with each other. The higher number of flowers was reported under paddy straw mulch which might be due to appropriate soil temperature and adequate moisture. The increased flower diameter under black polythene mulch might be due to the fact that it improves the soil physical, biological and chemical condition for better crop performance and by increasing the soil temperature $\left(16.4^{\circ} \mathrm{C}\right)$ and conserving moisture it provides favorable environment for better root growth. Goel et al., (2020) reported that mulching has beneficial effect on plant height and yield in potato.

\section{Weed parameters}

The use of different mulching material significantly affected the weed characters for pooled data of both the years as presented in Table 2. The weed count after 100 days was recorded minimum in black polythene mulch 100, 200 and $50 \mu(0.00,0.00$, and 0.50$)$, at par among each other. The maximum weed count was observed under weedy control (293.57) which differed significantly from other treatments. The fresh weight of weed after 100 days was recorded minimum in black polythene mulch 50, 100 and $200 \mu(0.00,0.00,0.00 \mathrm{~g})$ followed by white polythene mulch 200 $\mu(2.04 \mathrm{~g})$, at par among each other. The maximum fresh weight was observed under weedy control (366.42 g) which differed significantly from other treatments, followed by paddy straw mulch $(55.27 \mathrm{~g})$ and white polythene mulch $50 \mu(9.85 \mathrm{~g})$. The dry weight of weed after 100 days was recorded minimum in black polythene mulch 50, 100 and $200 \mu(0.00,0.00,0.00 \mathrm{~g})$ followed by white polythene mulch $200 \mu(0.093 \mathrm{~g})$, at par among each other. The maximum dry weight was observed under weedy control $(6.54 \mathrm{~g})$ which differed significantly from other treatments, followed by white polythene mulch $50 \mu$ (3.84 g) and paddy straw mulch (3.12 $\mathrm{g})$. The weed count as well as fresh and dry weight of weed was less in black polyethylene then white polyethylene mulch irrespective of different thickness. This might be due to the fact that black colour of the polyethylene absorbed all the incident radiations itself and there was least light penetration through the black polyethylene mulch which increased soil temperature $\left(16.4^{\circ} \mathrm{C}\right)$ and ultimately checked the weed seed germination and growth. These results are in conformity with Rajablariani et al., (2012).

\section{Soil temperature}

The soil temperature was recorded under different mulching material during the growth period of rose from October to February (Table 3). The average highest soil temperature was observed under black polyethylene mulch $200 \mu\left(14.1^{\circ} \mathrm{C}\right)$ followed by paddy straw mulch $\left(13.8^{\circ} \mathrm{C}\right)$. The maximum soil temperature was reported under black polyethylene mulch $200 \mu\left(16.4^{\circ} \mathrm{C}\right)$ in the month of October. There was difference of $0.9^{\circ} \mathrm{C}$ of soil temperature between black polyethylene mulch $200 \mu$ and weedy control in October. The black polythene mulch was more effective in increasing soil temperature due to absorption of greater net radiation under the mulch as compared to paddy straw (Yi et al., 2011). Modification of soil microclimate is positively related to increase harnessing of solar energy, improved plant growth and development and ultimate economic yield (Siakia et al., 2014). Thus, paddy straw mulch significantly improved the growth and flower quality of Rose by controlling the weed infestation as it resulted in maximum plant height, branches, number of flowers per plant and area whereas, irrespective of thickness no weed infestation were observed with black polythene mulch. The correlation coefficient value (0.082) between temperature and yield of flowers per plant indicated mulching induced higher soil temperature may be a useful practice to attain higher yield of flowers in rose.

Conflict of Interest Statement: The author (s) declares (s) that there is no conflict of interest.

Disclaimer: The contents, opinions and views expressed in the research article published in Journal of Agrometeorology are the views of the authors and do not necessarily reflect the views of the organizations they belong to.

Publisher's Note: The periodical remains neutral with regard to jurisdictional claims in published maps and institutional affiliations.

\section{REFERENCES}

Bohra, M., Kumar, S., Singh, C.P. (2015). Effect of mulch materials on growth parameters of rose (Rosa spp.) cv. "Laher". Int. J. Basic and Applied Agr. Res., 13(2):156-161.

Goel, L.,Shankar, V.and Sharma, R. K. (2020)Influence of organic mulches on soil hydrothermal and plant growth in potato. $J$. Agrometeorol., 22 (1): 56-59.

Hudu, A.I., Futuless, K.N. and Gworgwor, N.A. (2002). Effects of mulching intensity on the growth and yield of irrigated tomato (Lycopersicon esculentum Mill.) and weed infestation in semi-arid zone of Nigeria. J. Sustain. Agri., 21: $37-45$.

Rajablariani, H.R., Khan, F.H. and Rajazi, R. (2012). Effect of coloured plastic mulches on yield of tomato and weed biomass. Int. J. Env. Sci. Develop., 3(6):590-593.

Saha, G., Das, D., Lepcha, L. and Khan, S. (2010). Studies on leaf curl disease infection pressure and fruit yield of tomato as influenced by mulching and different meteorological variables. J. Agrometeorol., 12(1):138-140.

Saikia, U.S., Kumar, A., Das, S., Pradhan, R., Goswami, B., Wungleng, V.C., Rajkhowa D.J. and Ngachan, S.V. (2014). Effect of mulching on microclimate, growth and yield of mustard (Brassica juncea) under mid-hill condition of Meghalaya. J. Agrometeorol., 16(1): 144-145.

Yi, L., Yufang, S., Shenjiao, Y., Shiqing, L. and Fang, C. (2011). Effect of mulch and irrigation practices on soil water, soil temperature and the grain yield of maize (Zea mays $L)$ in Loess Plateau, China. Afr. J. Agri. Res., 6(10): 2175-2182. 